\title{
Topical Tacrolimus for Atopic Dermatitis: Euphoria and Vigilance
}

\author{
Jann Lübbe \\ Clinique et policlinique de dermatologie, Hôpital universitaire de Genève, Suisse
}

Today, there is ample scientific evidence for the clinical effectiveness, safety and patient comfort of tacrolimus ointment in the treatment of moderate to severe atopic dermatitis. Recent, well-documented reports on doubleblind, vehicle-controlled, randomized clinical studies encompass data from 419 adults [1] and 235 children [2] who were successfully treated with 0.1 and $0.03 \%$ tacrolimus ointment for up to 3 months. Concerning long-term treatment, two open studies have observed 316 adults [3] and 255 children [4] who were treated with $0.1 \%$ tacrolimus ointment for up to 1 year. Transient local burning and pruritus, occurring in every second patient, were the principal adverse effects, and there is apparently little risk of skin infections. This bright picture is endorsed by a significantly positive health-related quality of life assessment in 900 children and adults [5].

Tacrolimus ointment has not yet been released in most countries. For use in daily practice, a topical formulation is easily prepared from available FK-506 capsules on a prescription basis [6]. Most of the existing evidence on the treatment of atopic dermatitis with tacrolimus ointment stems from the particular clinical settings that are inherent in double-blind, randomized study protocols, not always representative of real-life conditions. One example is the steroid washout phase required by these studies prior to patient enrollment. Complete abstinence from any topical treatment throughout the resulting rebound phase is itself part of a rational treatment strategy for chronic atopic facial dermatitis. With the tacrolimus option at hand, management of this therapeutic cul-de-sac of the corticosteroid treatment era should be reversed [7], and therapeutic abstinence is likely to become obsolete in daily practice.

However, this realistic perspective raises questions that have not been answered by the clinical trials. Kawakami and coworkers, reporting in this issue of Dermatolo$g y$ [8], show that topical tacrolimus treatment of steroidaggravated facial atopic dermatitis is effective without a washout, and not associated with a rebound phenomenon. Remarkably, the authors have excluded patients with severe dermatitis from their study, as the use of topical tacrolimus on erosive lesions is officially prohibited in Japan, where the ointment is already marketed (Protopic). Erosive dermatitis increases the systemic absorption of the FK-506 molecule and is more prone to secondary bacterial or viral infection. Clinically infected atopic dermatitis also excluded patients from participation in the clinical trials. Early herpes simplex infection is much more difficult to spot amidst erosive, excoriated lesions. Is the above-mentioned assessment of the risk of infectious complications associated with tacrolimus ointment really representative of field conditions? Have a second look!

The two recent vehicle-controlled clinical studies report $22(3.4 \%)$ cases of herpes simplex infection during treatment with tacrolimus ointment, of which 3 presented as eczema herpeticum $[1,2]$. In the two open long-term studies, $31(5.4 \%)$ cases of herpes simplex infection were observed, of which 7 presented as eczema herpeticum [3, 4]. Taken together, every fifth herpes simplex infection diagnosed in these trials during tacrolimus treatment presented as an eczema herpeticum; in the vehicle-controlled

\begin{tabular}{ll}
\hline KARGER & ( ) 2001 S. Karger AG, Basel \\
Fax +41 613061234 & 1018-8665/01/2031-0001\$17.50/0 \\
$\begin{array}{l}\text { E-Mail karger@karger.ch } \\
\text { www.karger.com }\end{array}$ & $\begin{array}{l}\text { Accessible online at: } \\
\text { www.karger.com/journals/drm }\end{array}$
\end{tabular}

Dr. Jann Lübbe

Clinique et policlinique de dermatologie et de vénéréologie

Hôpital cantonal universitaire de Genève

24, rue Micheli-du-Crest, CH-1211 Genève 14 (Switzerland)

E-Mail jann.lubbe@hcuge.ch 
trial with children alone [2], every third case of herpes simplex infection had disseminated during the treatment! Within the trials, herpes dissemination occurred exclusively in association with tacrolimus treatment; $5(0.75 \%)$ cases of herpes simplex infection were reported from the vehicle-treated groups. The overall incidence of herpes simplex infections reported in these trials $(58 / 1,553$; $3.75 \%$ ) is not unusual for a population with moderate to severe atopic dermatitis; the rate of conversion from herpes simplex infection to eczema herpeticum within the treated study collective is certainly not a 'quantité négligeable'!

The risk of acute infectious complications during treatment with tacrolimus ointment is not a major problem if the prescribing dermatologist as well as the treated patient are informed, and rational precautions are respected. However, atopic dermatitis is a benign disease, and the uncertainty regarding the consequences of a long-term local immunosuppression, especially on sun-exposed skin sites, endows our specialty with a responsibility as challenging as the therapeutic perspectives. Therefore, vigilance is more appropriate than euphoria, at times when immunomodulation of atopic dermatitis with the Tsukuba macrolide immunosuppressor becomes clinical routine. The acquisition of the necessary clinical expertise relies on a continuous effort to adapt clinical guidelines, based on careful documentation and communication of whatever is not yet evidence based in treating atopic dermatitis with topical tacrolimus: it's time for 'tacro surveillance'!

\section{References}

1 Soter N, Fleischer A, Webster G, Monroe E, Lawrence I: Tacrolimus ointment for the treatment of atopic dermatitis in adult patients. II. Safety. J Am Acad Dermatol 2001;44(suppl 1): S39-S46.

2 Paller A, Eichenfield L, Leung D, Steward D, Appell M: A 12-week study of tacrolimus ointment for the treatment of atopic dermatitis in pediatric patients. J Am Acad Dermatol 2001; 44(suppl 1):S47-S57.

3 Reitamo S, Wollenberg A, Schöpf E, Perrot J, Marks R, Ruzicka T, et al: Safety and efficacy of 1 year of tacrolimus ointment monotherapy in adults with atopic dermatitis. Arch Dermatol 2000;136:999-1006.
4 Kang S, Lucky A, Pariser D, Lawrence I, Hanifin J: Long-term safety and efficacy of tacrolimus ointment for the treatment of atopic dermatitis in children. J Am Acad Dermatol 2001; 44(suppl 1):S58-S64.

5 Drake L, Pendergast M, Maher R, Brenemann D, Korman N, Satoi Y, et al: The impact of tacrolimus ointment on health-related quality of life of adult and pediatric patients with atopic dermatitis. J Am Acad Dermatol 2001; 44(suppl 1):S65-S72.
6 Aoyama H, Tabata N, Tanaka M, Uesugi Y, Tagami H: Successful treatment of resistant facial lesions of atopic dermatitis with $0.1 \%$ FK-506 ointment. Br J Dermatol 1995;133: 494-496.

7 Nghiem P: 'Topical immunomodulators?': Introducing old friends and a new ally, tacrolimus. J Am Acad Dermatol 2001;44:111-113.

8 Kawakami T, Soma Y, Morita E, Koro O, Nakamura K, Tamaki K, Yajima K, Imaizumi A, Matsunaga R, Murakami N, Kashima M, Mizoguchi M: Safe and effective treatment of refractory facial lesions in atopic dermatitis using topical tacrolimus following corticosteroid discontinuation. Dermatology 2001;203: 32-37. 